\title{
Effect of Water Quality Characteristics on Fish Population of the Lake Volta, Ghana
}

Elegbede Isa Olalekan ${ }^{1}$, Fatima Kies ${ }^{2}$, Lawal-Are Aderonke Omolara ${ }^{3}$, Salau Damilola Rashidat ${ }^{4}$, Fashina-Bombata Hakeem ${ }^{5}$, Akintola Shehu Latunji ${ }^{5}$, Aderolu Ademola Zaid ${ }^{3}$, Ndimele Emeka ${ }^{5}$, Onyema Ikenna Charles ${ }^{3}$ and Fadeyi Oluwaseun ${ }^{6}$

${ }^{1}$ Department of Environmental Planning, Brandenburg University of Technology, Cottbus-Senftenberg, Germany.

${ }^{2}$ Department of Earth and Environmental Sciences, Università Degli Studi di Milano-Bicocca

Milano, Lombardy, Italy.

${ }^{3}$ Department of Marine Sciences, University of Lagos, Akoka, Lagos, Nigeria.

${ }^{4}$ Department of Ecotoxicology, Institute for Environmental sciences, University of Koblenz-Landau, Landau, Germany.

${ }^{5}$ Department of Fisheries, Lagos State University, Ojo, P.O Box 10123, LASU, Lagos, Nigeria.

${ }^{6}$ Department of Geology, Faculty of Environmental Sciences, University of Trier, Behringstraße 21, 54296 Trier, Germany.

\begin{abstract}
This study examines the effect of physicochemical parameters on different categories of fish species; benthopelagic, pelagic and demersal on Lake Volta. The methods of this study were based on the estimation of hydrographic data, collection and analysis of physicochemical parameters of the water samples. Fish samples were collected from four sampling stations namely Oti River at Sabra, White Volta at Daboya, Black Volta at Bamboi and Lower Volta at Amedeka. This review work studies a study which was carried out between February 1995 and January, 1996. A statistical analysis was conducted. Water resource availability and mean annual rainfall of Lake Volta were highest in Black Volta and Oti River respectively. The results show pH 194-520, Conductivity $\left(\mu \mathrm{cm}^{-1}\right)$, Dissolved oxygen 8.0- $11.2(\mathrm{mg} / \mathrm{L})$, Biological Oxygen Demand (BOD) 2.7-105 (mg/L), Alkalinity 35.3-53.8 (mg/L), Chloride 4.6-13.6 (mg/L), Calcium 4.8-10.1 (mg/L), Total Hardness 17.4-44.1 (mg/L), Magnesium 2.5-8.3 (mg/L), Ammonia-N 0.4-1.6 (mg/L), Phosphate 0.2-0.9 (mg/L), Nitrate 0.2-6.6 (mg/L), Nitrite 0.06-0.6 (mg/L) and Sulfate 1.2-8.9 (mg/L) respectively. The benthopelagic, pelagic and demersal fish population show 16, 6 and 11 number of different fish species respectively in the lake. The study concludes that the quality of the water is satisfactory when compared with other lakes. Anthropogenic activities is insignificant on the aquatic habitat and the appreciable fish population is an indication of good biological quality of the water body.
\end{abstract}

Keywords: Species; Fisheries; Pollution; Trophic level; Rainfall; Akomombo

\section{Introduction}

Lake Volta occupies about $4 \%$ of the area of Ghana. It is recorded as the largest man- made Lake, which is the largest of its kind and has provided enormous biological and socio economic benefit like generation of electricity (1060 MW) at Akosombo and Kpong dam [1]. The Lake Volta is a highly significant water body richly surrounded by Togo, Cote d'Ivoire, Mali, Benin and Burkina Faso distributing the largest drains in the Lake Basin [2]. It is drained by several major rivers: the Mouhoun (Black Volta), the Nakambe (White Volta) with the Nazinon (Red Volta) as its tributary, the Oti River and the Lower Volta [2]. The construction of the Lake in 1964 was purposely for hydroelectric power generation, which had necessitated the uprising of other West Africa lake like Koussou Lake in Cote D' Ivore, Kariba Lake in Zimbabwe and Kainji Lake in Nigeria [3]. All these lakes are promotional aquatic inland biodiversity with abundant species of flora and fauna particularly enhancing regional fisheries market. The lake is attributed to various prospects and opportunities such as transportation, regional fishery trade, enhancement of livelihood. The lake is an ecologically formed reservoir whose biological development is by any of these namely: deformation of the original flora and fauna abundance and further decolonization by other species; production of plankton which is from primary and secondary production and an establishment of non-permanent plant and animal communities which leads to a period of ecological stabilization [4].

Lake Volta contributes between 80 and $90 \%$ of fish catches from the inland fisheries of Ghana [5]. In order to meet consumer needs, maintenance of the quality, diversity and availability of fish in sufficient quantities must be promoted. The lake is influenced by numerous anthropogenic impact. The physicochemical characteristics is affected which has uploaded negative effect on fish population in the Lake. It is pertinent to critically evaluate the effect of water quality characteristics on the fish population of Lake Volta, Ghana for proper sustainability and decision-making process in the region [6]. This paper is based on review study which focuses on physicochemical parameters of Lake Volta and the evaluation of its fish population. The aim of this review study is to examine the biological, physical and chemical water quality parameters including composition and distribution of fish population in the lake.

\section{Materials and Methods}

\section{Study area}

The Volta Lake is located in Ghana, West Africa. It lies between latitudes $5^{\circ} 30^{\prime} \mathrm{N}-14^{\circ} 30^{\prime} \mathrm{N}$ and longitudes $2^{\circ} 00^{\prime} \mathrm{E}-5^{\circ} 30^{\prime} \mathrm{W}$, which stretches for a length of $520 \mathrm{~km}^{2}$ from the Northern part to the southern part of Akosombo dam [7]. It is part of a river basin component which occupies $417,382 \mathrm{~km}^{2}$ and follows a part of a basin which is elevated from sea level to a height of $920 \mathrm{~m}$ to an average elevation of $257 \mathrm{~m}$

*Corresponding author: Elegbede Isa Olalekan, Department of Environmental Planning, Brandenburg University of Technology, Cottbus-Senftenberg, Germany, Tel: +49 0355 690; E-mail: isaelegbede@gmail.com

Received March 05, 2015; Accepted August 21, 2015; Published August 24 2015

Citation: Elegbede IO, Kies F, Omolara LAA, Rashidat SD, Hakeem EB, et al. (2015) Effect of Water Quality Characteristics on Fish Population of the Lake Volta, Ghana. J Environ Anal Toxicol 5: 317. doi:10.4172/2161-0525.1000317

Copyright: @ 2015 Olalekan El, et al. This is an open-access article distributed under the terms of the Creative Commons Attribution License, which permits unrestricted use, distribution, and reproduction in any medium, provided the original author and source are credited. 
between the lowest channel and the highest channel [8]. The Volta Lake is fed by some major appendages, from the Black Volta river, or Nakambe river, to the White Volta river or Nazinon river, Afram river and finally to the Oti river which drains $72,000 \mathrm{~km}^{2}$ of northwestern Benin and Togo (Figure 1) [8]. These tributaries join in northern Ghana to form Lake Volta [7].

\section{Sampling of chemical parameters}

Data on the lake was collected between February 1995 and January 1996. It covered four sampling stations namely Oti River at Sabra, White Volta at Daboya, BlackVolta at Bamboi and Lower Volta at Amedeka, the sampling stations were chosen because they represent major parts of the lake. Sampling was done randomly at portions of the water course and each station was sampled in triplicate for 12 times from February 1995 to January 1996. All the water samples were taken with a water sampler. The lake was sampled under base flow conditions, about 20 - $30 \mathrm{~cm}$ deep from the surface [9]. Water samples for physicochemical analyses were collected into clean 1-litre plastic bottles. Temperature, conductivity, salinity and $\mathrm{pH}$ were measured in situ using a Horiba V-10 meter with combined electrodes [10]. Dissolved oxygen (DO) was measured using a DO meter, YSI Model 5I B [11]. Samples for Biochemical Oxygen Demand (BOD) were collected into dark painted glass bottles and were incubated at $20^{\circ} \mathrm{C}$ for 5 days before the remaining Dissolved oxygen was determined. All the samples were stored in cold boxes and, on return to the laboratory analyzed for physicochemical constituents [12]. Physicochemical parameters were determined at the sites and the collected water samples formed the basis for assessing the quality of the lake.

\section{Laboratory analyses}

The laboratory analyses were undertaken according to procedures outlined in Standard Methods for the Examination of Water and Wastewater, 20th edition [11]. The methods employed for the analyses were summarized as follows:

1. Suspended solids (SS): membrane filtration, followed by drying at $105^{\circ} \mathrm{C}$ and weighing.

2. Total phosphate: sulphuric acid/per sulfate digestion followed by reaction with ammonium molybdate and ascorbic acid to form a blue molybdate complex, whose intensity was measured at 880 $\mathrm{nm}$ using UV spectrophotometer.

3. Kjeldahl nitrogen: acid digestion in the presence of selenium catalyst followed by determination of ammonia-nitrogen.

4. Ammonia nitrogen: direct Nesslerisation and spectrophotometric determination.

5. Nitrate-nitrogen: reaction with Brucinesulfanilic acid, which produced a yellow color and measured spectrophoto- metrically at $410 \mathrm{~nm}$.

\section{Fish sampling}

The fish species studied were collected from four sampling sites, namely Oti River at Sabra, White Volta at Daboya, Black Volta at Bamboi and Lower Volta at Amedeka during the year 1995 and 1996. Fish were captured with a battery of gill nets $(2.5 \mathrm{~m}$ height $\times 25 \mathrm{~m}$ long) of $20,25,30,35,40$ and $50 \mathrm{~mm}$ mesh size. Gill nets were set in the afternoon (17:00-21:00) and in the morning (5:00-9:00). Each site was sampled during one or two consecutive days, each individual, standard length (distance from the tip of the snout to the ultimate vertebrate) and weight were measured, sex was determined by gonad observation.
The four sites are part of an interconnected river system and are not; therefore, strictly independent in space [13]. The fishes were preserved in $10 \%$ formaldehyde solution for taxonomic analysis. Identification and economic importance of fishes was carried [14]

\section{Data analysis}

The Statistical analysis of the research was performed using Microsoft Excel 2010 and Statistical Package for the Social Sciences (SPSS) (version 12.0, SPSS Incorporation, Chicago, II, USA) based on [8] statistical differences and significance in concentrations were also analyzed using non-parametric analysis of mean, standard deviation, standard error and Mann-Whitney U-test for the 3 sampling locations [8]

\section{Results}

\section{Hydrographic estimation of Lake Volta}

Figure 2 shows water resource availability and Figure 3 shows mean annual rainfall of Lake Volta, between February 1995 and January 1996. Windows, since most concentrations were not normally distributed, non-parametric analysis was performed, a probability value of $P<0.05$ was considered as statistically significant in the study [8]. Black river has the highest water resources availability by area and the Lower River shows the lowest water availability by area in $\mathrm{km}^{2}$. Average annual rainfall was highest in Oti River and lowest in Black River while White and Lower River almost show the same values.

\section{Physicochemical characteristics of Lake Volta}

Physicochemical parameters of water samples from the four sample stations of Lake Volta are presented. Mean values of physicochemical parameters in relation to different depth $(\mathrm{m})(0,2,6$ and 10) of Lake Volta, February 1995- January 1996 are presented in Table 1.

The physicochemical parameter presented is expressed based on the depth range of 0 to $10 \mathrm{~m}$. The temperature ranges from 29.4 to $31.0^{\circ} \mathrm{C}$. The $\mathrm{pH}$ shows ranges of 6.9 to 7.2 , while the Dissolved Oxygen $(\mathrm{DO})(\mathrm{mg} / \mathrm{L})$ ranges between 6.5 and $8.1(\mathrm{mg} / \mathrm{L}) . \mathrm{O}_{2}$ saturation ranges between 85.2 and $108.9 \%$. The BOD shows non availability in depth 2

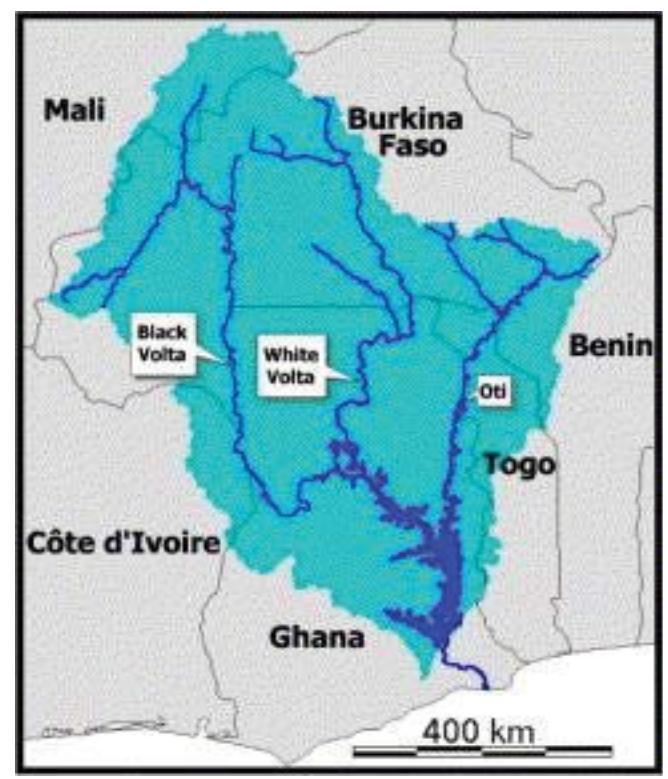

Figure 1: Map of Volta Lake. 


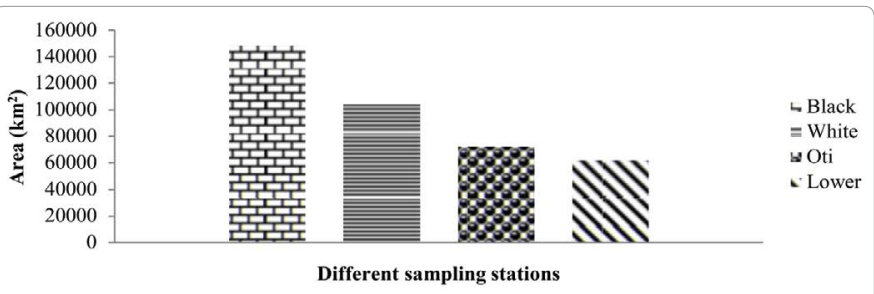

Figure 2: Water resources availability of Lake Volta, February 1995-January 1996.

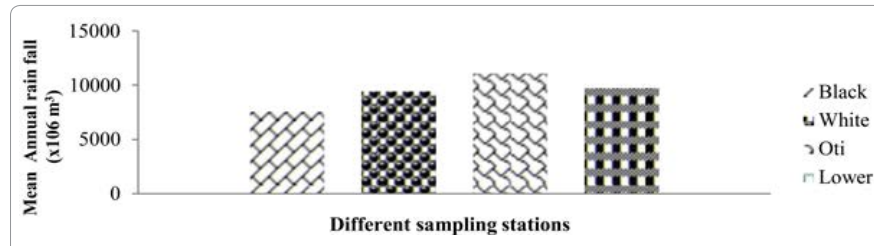

Figure 3: Mean annual rainfall of Lake Volta, February 1995- January 1996.

\begin{tabular}{|l|c|c|c|c|}
\hline \multicolumn{5}{|c}{ Depth $(\mathbf{m})$} \\
\hline Physicochemical factor & 0 & 2 & 6 & 10 \\
\hline Temperature $\left({ }^{\circ} \mathrm{C}\right)$ & 31.0 & 30.0 & 29.5 & 29.4 \\
\hline $\mathrm{pH}$ & 7.2 & 7.2 & 7.0 & 6.9 \\
\hline $\mathrm{DO}(\mathrm{mg} / \mathrm{l})$ & 8.1 & 7.9 & 7.2 & 6.5 \\
\hline $\mathrm{O}_{2}$ saturation $(\%)$ & 108.9 & 103.9 & 94.1 & 85.2 \\
\hline $\mathrm{BOD}(\mathrm{mg} / \mathrm{l})$ & 3.9 & $\mathrm{Na}$ & $\mathrm{Na}$ & $\mathrm{Na}$ \\
\hline Alkalinity $\left(\mathrm{mg} / \mathrm{l} \mathrm{CaCO}{ }_{3}\right)$ & 44.3 & 44.3 & 41.7 & 40.2 \\
\hline TDS $(\mathrm{mg} / \mathrm{l})$ & 25.2 & 25.8 & 25.0 & 24.5 \\
\hline Conductivity $(\mu \mathrm{S} / \mathrm{cm})$ & 84 & 79 & 76 & 76 \\
\hline Sodium $(\mathrm{mg} / \mathrm{l})$ & 12.1 & 9.6 & 11.0 & 12.1 \\
\hline Phosphate $(\mathrm{mg} / \mathrm{l})$ & 0.41 & 0.34 & 0.36 & 0.50 \\
\hline Nitrate $(\mathrm{mg} / \mathrm{l})$ & 0.51 & 0.63 & 0.66 & 0.82 \\
\hline Nitrite $(\mathrm{mg} / \mathrm{l})$ & 0.02 & 0.02 & 0.02 & 0.02 \\
\hline Ammonia-nitrogen $(\mathrm{mg} / \mathrm{l})$ & 0.83 & 0.33 & 0.36 & 0.57 \\
\hline Secchi disc depth $(\mathrm{cm})$ & 50.2 & 0 & 0 & 0 \\
\hline
\end{tabular}

Table 1: Mean value of physicochemical parameters of Lake Volta, February 1995-January 1996 ( Na: Not available).

$\mathrm{m}, 6 \mathrm{~m}$ and $10 \mathrm{~m}$ but $3.9(\mathrm{mg} / \mathrm{L})$ in $0 \mathrm{~m}$ depth. Alkalinity value ranges from 40.2 and $44.3 \mathrm{mg} / \mathrm{L}$ for depth $10 \mathrm{~m}$ and $2 \mathrm{~m}$ respectively. The TDS values ranges from 25.0 and $25.8 \mathrm{mg} / \mathrm{L}$ in depth of $6 \mathrm{~m}$ and $2 \mathrm{~m}$ respectively. Conductivity shows the same values of $76 \mu \mathrm{Scm}^{-1}$ for depth $6 \mathrm{~m}$ and $10 \mathrm{~m}$ while depth $0 \mathrm{~m}$ shows a highest value of $84 \mu \mathrm{Scm}^{-1}$. The highest value of $12.1(\mathrm{mg} / \mathrm{L})$ at $0 \mathrm{~m}$ depth and lowest value of $9.6(\mathrm{mg} / \mathrm{L})$ at $2 \mathrm{~m}$ was shown. Nitrate and nitrite have the highest values 0.82 and $0.02(\mathrm{mg} / \mathrm{L})$ and lowest values of 0.51 and $0.02(\mathrm{mg} / \mathrm{L})$ respectively. Ammonia-nitrogen ranges between 0.33 and $0.83(\mathrm{mg} / \mathrm{L})$ for $2 \mathrm{~m}$ and $0 \mathrm{~m}$ respectively while there is only clearness at $0 \mathrm{~m}$ depth of $50.2 \mathrm{~cm}$ based on the Secchi disc depth.

Mean $\mathrm{pH}$ value is 6.9 and 7.1 for Oti and lower Volta River respectively. Mean Dissolved oxygen is 8.0 at Lower Volta but 9.9 at Oti River. Alkalinity of $53.8 \mathrm{mg} / \mathrm{L}$ is highest in Black Volta and lowest in Oti River. Chloride of $13.6(\mathrm{mg} / \mathrm{L})$ is highest in White Volta and lowest value of $4.6(\mathrm{mg} / \mathrm{L})$ in Lower Volta is recorded, calcium was highest in Black Volta and lowest in Oti River. Total hardness value is highest in Black Volta $44.1(\mathrm{mg} / \mathrm{L})$ and lowest value of $17.4(\mathrm{mg} / \mathrm{L})$ in Lower Volta River. Phosphate, nitrate, nitrite and sulfate show values between 0.2 , $0.2,0.06,1.2 \mathrm{mg} / \mathrm{L}$ and $0.9,6.6,0.6,8.9 \mathrm{mg} / \mathrm{L}$ for Oti, White Volta, Black Volta and Lower Volta River respectively (Table 2).
Fish population in the benthopelagic, pelagic and the demersal region of Lake Volta

Table 3 shows fish population of the benthopelagic region of Lake Volta between February 1995 and January 1996. Table 4 shows pelagic fish species for the same region and period. Clarias gariepinus has the highest total length of $170 \mathrm{~cm}$ while Barbus macrops has the lowest maximum total length. Malapterurus electricus has the highest trophic level of 3.93 and Synodontis eupterus has the lowest trophic level of 2.88. The Hemichromis fasciatus shows a moderate trophic level, The Arius gigas also shows a higher trophic level.

For the fish population in pelagic region of Lake Volta, February 1995-January 1996 (Table 4). The pelagic fish species of Lake Volta Brycinus leuciscus shows the highest reproductive value of 1.20 whereas Brycinus macrolepidotus shows the highest maximum total length of $65 \mathrm{~cm}$ and Brycinus luteus shows the lowest maximum total length of $10 \mathrm{~cm}$ and the highest trophic level of 2.93. Table 5 shows fish population in demersal region of Lake Volta; it shows highest value of maximum total length of $204 \mathrm{~cm}$ for Gymnarchus niloticus and lowest value of 25 for Ctenopoma kingsleyea respectively. Hepsetus odoe shows the highest trophic level of 4.50 and lowest trophic level of 2.00 for Citharinus citharus respectively. The Citharinus citharus has the highest reproductive value of 0.33 while the Heterobranchus longifilis has the lowest resilience value of 0.11 .

\section{Discussion}

\section{Physicochemical characteristics of Lake Volta}

Physicochemical parameters of dissolved oxygen level recorded in this study was higher compared to $3.0-0.7(\mathrm{mg} / \mathrm{L})$ recorded for water quality, abundance of fish and Plankton species of Ikwori Lake, Nigeria $[15,16]$ explains that the possible reason for oxygen values in this study indicates an organic enrichment in the lakes. The values of dissolved oxygen fell within the ranges $5.0-9.0(\mathrm{mg} / \mathrm{L})$, which is in agreement with [17] for good water quality suitable for aquatic organisms. All $\mathrm{pH}$ values in this study agree with the work of of Trevidi and Kataria (2012) [18] for $\mathrm{pH}$ values of Shahpura Lake and pollution have effects on the ground water of its fringe areas. Total dissolve solid $(\mathrm{mg} / \mathrm{L})$ in this study was lower than the results of $96-109(\mathrm{mg} / \mathrm{L})$ [15] which was due to reduced anthropogenic and agricultural activities around Lake Volta. The conductivity observed was low due to the indication of the freshwater habitats for low salinity. The values are lower than 47,667

\begin{tabular}{|l|c|c|c|c|}
\hline & $\begin{array}{c}\text { Oti River at } \\
\text { Sabra }\end{array}$ & $\begin{array}{c}\text { White Volta } \\
\text { at Daboya }\end{array}$ & $\begin{array}{c}\text { Black Volta } \\
\text { at Bamboi }\end{array}$ & $\begin{array}{c}\text { Lower Volta } \\
\text { at Amedeka }\end{array}$ \\
\hline $\mathrm{pH}$ & $6.9+0.5$ & $6.9+0.4$ & $7.0+0.5$ & $7.1+0.3$ \\
\hline Conductivity $(\mu \mathrm{S} / \mathrm{cm})$ & $280+213$ & $194+156$ & $201+154$ & $520+245$ \\
\hline Dissolved Oxygen $(\mathrm{mg} / \mathrm{l})$ & $9.9+2.4$ & $10.6+3.8$ & $11.2+3.1$ & $8.0+2.0$ \\
\hline Alkalinity $(\mathrm{mg} / \mathrm{l})$ & $35.3+11.5$ & $42.6+16.5$ & $53.8+23.6$ & $44.8+6.4$ \\
\hline Chloride $(\mathrm{mg} / \mathrm{l})$ & $5.4+2.8$ & $13.6+8.6$ & $7.0+0.8$ & $4.6+2.5$ \\
\hline Calcium $(\mathrm{mg} / \mathrm{l})$ & $4.8+2.0$ & $6.8+2.0$ & $10.1+2.9$ & $5.3+1.4$ \\
\hline Total Hardness $(\mathrm{mg} / \mathrm{l})$ & $22.9+10.8$ & $30.4+2.8$ & $44.1+18.6$ & $17.4+7.3$ \\
\hline Magnesium $(\mathrm{mg} / \mathrm{l})$ & $4.3+2.2$ & $5.8+0.8$ & $8.3+4.1$ & $2.5+1.9$ \\
\hline Ammonia-N(mg/l) & $1.0+1.5$ & $1.6+2.9$ & $1.5+2.4$ & $0.4+0.5$ \\
\hline Phosphate(mg/l) & $0.9+0.4$ & $0.7+1.0$ & $0.6+1.9$ & $0.2+0.3$ \\
\hline Nitrate $(\mathrm{mg} / \mathrm{l})$ & $0.2+0.1$ & $0.5+0.6$ & $0.2+0.1$ & $6.6+10.9$ \\
\hline Nitrite $(\mathrm{mg} / \mathrm{l})$ & $0.08+0.02$ & $0.06+0.08$ & $0.1+0.1$ & $0.6+1.3$ \\
\hline Sulfate $(\mathrm{mg} / \mathrm{l})$ & $5.7+6.6$ & $8.9+10.7$ & $7.0+8.4$ & $1.2+0.8$ \\
\hline
\end{tabular}

Table 2: Summary of water quality at the sampling stations on Oti, White, Black and Lower Volta. 


\begin{tabular}{|l|c|c|}
\hline \multicolumn{1}{|c|}{ Species } & Maximum total length $(\mathrm{cm})$ & Trophic level \\
\hline Alestes baremoze & 43 & 3.05 \\
\hline Arius gigas & 165 & 3.86 \\
\hline Bagrus docmak & 71 & 4.08 \\
\hline Barbus macrops & 12 & 3.04 \\
\hline Brienomyrus niger & 16 & 3.25 \\
\hline Clarias gariepinus & 170 & 3.15 \\
\hline Ctenopoma petherici & 18 & 3.16 \\
\hline Emichromis bimaculatus & 17 & 3.93 \\
\hline Hemichromis fasciatus & 25 & 3.18 \\
\hline Malapterurus electricus & 149 & 2.93 \\
\hline Synodontis clarias & 44 & 2.98 \\
\hline Synodontis eupterus & 37 & 2.65 \\
\hline Synodontis filamentosa & 32 & 2.88 \\
\hline Synodontis membranaceus & 61 & 3.11 \\
\hline Synodontis nigrita & 22 & 2.89 \\
\hline Synodontis ocellifer & 49 & 3.12 \\
\hline
\end{tabular}

Table 3: Benthopelagic fish species of Lake Volta, February 1995-January 1996.

\begin{tabular}{|l|c|c|}
\hline \multicolumn{1}{|c|}{ Species } & Maximum total length (cm) & Trophic level \\
\hline Alestes dentex & 55 & 2.93 \\
\hline Brycinus leuciscus & 15 & 2.91 \\
\hline Brycinus longipinnis & 15 & 2.18 \\
\hline Brycinus luteus & 10 & 2.93 \\
\hline Brycinus macrolepidotus & 65 & 2.34 \\
\hline Brycinus nurse & 25 & 2.44 \\
\hline
\end{tabular}

Table 4: Pelagic fish species of Lake Volta, February 1995-January 1996.

\begin{tabular}{|l|c|c|}
\hline \multicolumn{1}{|c|}{ Species } & Maximum total length (cm) & Trophic level \\
\hline Chrysichthys auratus & 43 & 3.66 \\
\hline Chrysichthys nigrodigitatus & 80 & 2.58 \\
\hline Citharinus citharus & 71 & 2.00 \\
\hline Ctenopoma kingsleyea & 25 & 3.19 \\
\hline Gymnarchus niloticus & 204 & 3.71 \\
\hline Hepsetus odoe & 70 & 4.50 \\
\hline Heterobranchus bidorsalis & 150 & 3.69 \\
\hline Heterobranchus isopterus & 90 & 3.61 \\
\hline Heterobranchus longifilis & 183 & 3.72 \\
\hline Hyperopisus bebe & 63 & 3.60 \\
\hline Lates niloticus & 200 & 4.48 \\
\hline
\end{tabular}

Table 5: Demersal fish species of Lake Volta, February 1995-January 1996.

and $24,100 \mu \mathrm{S} \mathrm{cm}^{-1}$ for water quality characteristics at the estuary of Korle Lagoon in Ghana [12] also gave possible reasons for the lower conductivity value, which could be ascribed to the low primary source of domestic water and sewage in the lake to most of these towns [19]. BOD value of more than $8 \mathrm{mg} / \mathrm{L}$ is an indicative of moderate pollution (Martin, 1970). BOD values of $12 \mathrm{mg} / \mathrm{L}$ or more are considered grossly polluted [12]. The higher value of BOD in White Volta at Daboya is attributed to increased human induced impact of the area. BOD therefore is an important parameter of water, which expresses the health scenario of freshwater bodies [20]. The alkalinity level of the present study was in agreement with the values of [21] on the effect of rain on aquatic physicochemical parameters. Chloride content in River Usuma varied from $0.05-2.18(\mathrm{mg} / \mathrm{L})$ which is very much higher than the values of this work. The values of chloride observed in this study are not significant when compared to tolerable values posted by United States Environmental Protection Agency (USEPA) though chloride contents in water are not harmful. Chloride concentration at different sampling sites did not exhibit a clear trend with respect to point or non-point pollution sites [22]. Magnesium values of the present study were lower than the values of magnesium of $10.1(\mathrm{mg} / \mathrm{L})$ for Weija Reservoir [9]. The nitrate and nitrite in form of $\mathrm{N}$ in this present study are within the range of values considered favorable for lifetime consumption which is between 6 and $9(\mathrm{mg} / \mathrm{L})$ based on the World Health Organization (WHO) guidelines for tropical South Africa, [23]. The phosphate in this study is high at $10 \mathrm{~m}$ depth. Lakes deepest depth sinks phosphorous and settles to the strata then covered with sediments. At high temperature the phosphorus are released back, which enhance phytoplankton multiplication including aquatic vegetation, hence provide nutrients for demersal herbivore fish [24,25]. The sulfate values of this study are lower than the sulfate values of 101.4 to $344.1(\mathrm{mg} / \mathrm{L})$ of water quality parameters of River Usuma in Nigeria due to the fact that sulfate [22]. This is due to the fact that the area of study does not have major industrial activites around, salt from ocean are not accounted for. For most lakes, sulphate concentrations is range between 2 and $30 \mathrm{mg} / \mathrm{L}$. the value of study fall within the these range which is also favorable for survial of aquatic organism [26].

The sulfate values of a Plankton-Based Assessment of the Trophic State of Three Tropical Lakes in Cross River, Nigeria in ref. [15] are higher than the values of this study based on the circumstance that low sulfate concentrations occur in organic rich water especially at time of low water discharge and high temperature of summer season [27]. The nitrate, phosphate and sulfate in this study are important parameters of aquatic water bodies, they show the pollution status and anthropogenic load in the water habitat [28]. The populations of fish in the lake Volta survive well as its shown in the values of the physicochemical parameters and their abundance are shown below.

\section{Fish population of Lake Volta}

The lake is rich in fish fauna [2]. About 121 species have been recorded on Lake Volta, during pre-impoundment phase and filling stage. The species list recorded during the filling stage is likely to change mostly due to the upgraded taxonomy of the species attributed to the region and also to the disappearance of some fish species as a consequence of the change from riverine to lacustrine conditions [2935]. 41 different fish species were observed in this study, which is very low compared to the original fish species of the lake. The reduction in current estimate is due to over exploitation of the fish resources, [2] and particularly the fluctuations in the physicochemical characteristics of the fish. Diversification is observed in the trophic level, fish species with the highest trophic level indicates increased feeding in different regions of habitat.

\section{Conclusions}

Aquatic habitats of Lake Volta are a large expanse of water, the largest part of the lake is the Lower River. The maximum amount of annual rainfall is recorded and observed at the Oti River of the lake in Ghana. Water quality of Lake Volta is generally safe and within the recommended limit of freshwater and similar lakes around the world. There are some sampling locations with altered physicochemical parameters. The most dominant fish species with high trophic level in the benthopelagic habitat are Bagrus docmak, Arius giga and Emichromis bimaculatus, while Alestes dente, Brycinus leucisc and Brycinus luteus are dominant in the pelagic region. Hepsetu odoe, Lates niloticus, Bagrus bajad and Heterobranchus bidorsalis were dominant in the demersal region of Lake Volta. The trophic level abundance of these species is related to their resistance to uniform aquatic degradation. Effective monitoring and frequent assessment of the lake is highly 
crucial and controlling of anthropogenic activities around the lake. This research work is a great tool for decision making by the Ghanaian government especially in water resource management for limnological purpose. Lake Volta is an important resource for the Africa community especially Ghana, adequate monitoring and controlling of the habitat is required to maintain the diversity and richness of fish species and other economically important species. Likely anthropogenic activities around the water environment should be discouraged and proper enlightenment and education of the dwellers of the Lake Basin environment should be encouraged.

\section{Acknowledgement}

Our appreciation is directed to some of the staff of the Brandenburg University of Technology, Cottbus-Senftenberg, Germany, who supported this study research. We acknowledge the support of the colleagues in the academic community who added value to the success of this work. Our thanks are deeply directed to the reviewers and the editorial board for their constructive peer reviewed job.

\section{References}

1. Fobil JN, Attuquayefio DK 2003) Remediation of the Environmental Impacts of the Akosombo and Kpong Dams. Horizon International, Yale University, Yale.

2. Bene C (2007) Diagnostic study of the Volta Basin fisheries Part 1 - overview of the Volta basin fisheries resources, Cairo, Egypt: WorldFish Center Regional Offices for Africa and West Asia.

3. Amakye JS (2001) Some observations on macro-invertebrate benthos of Lake Volta at Yeji Area. West Afr J Appl Ecol 2: 91-103.

4. Likens GE (2010) Lake Ecosystem Ecology. Elsevier Academic Press (1st edn) $1-480$.

5. Ofori-Danson PK (2002) Trophic relationships and spawning habits of post impoundment fish stocks of Lake Volta in Ghana. Ghana Sci J 42: 61-70.

6. Akongyuure DN, Ofori-Danson PK, Nunoo FK (2012) Selectivity and fish catches of gillnets in stratum VII (Yeji sector) of Lake Volta for sustainable management. International Journal of Fisheries and Aquaculture 4: 41-54.

7. Diei-Ouadi $Y$, Mensah M (2005) Improving livelihoods through exporting artisanally processed fish, Rome: FAO.

8. Barry B, Obuobie E, Andreini M, Andah W, Pluquet M (2005) The Volta rive basin. Comprehensive assessment of water management in agriculture. Comparative study of river basin development and management. International Water Management Institute.

9. Asante KA, Quarcoopome T, Amevenku FY (2008) Water quality of the Weija Reservoir after 28 years of impoundment. West African Journal of Applied Ecolog, 13: 171- 180

10. Mrcelic GJ, Sliskovic M (2010) The Impact of Fish Cages on Water Quality in One Fish Farm in Croatia. World Academy of Science, Engineering and Technology 44: 963-966.

11. American Public Health Association. APHA (1995) Standard methods for the examination of water and wastewater. American Public Health Association, American Water Works association, Water Environment Federation, Washington

12. Karikari AY, Asante KA, Biney CA (2006) Water Quality Characteristics at the Estuary of Korle Lagoon in Ghana. West Africa Journal of Applied Ecology 10: 73-85.

13. Lopez ES, Pouilly M, Vallejos A, Perez T, Rejas D (2012) Effect of water quality on growth of four fish species in the Iténez basin (Upper Madera, Amazon). Environ Biol Fish 95: 371-381.

14. Kantaraj GS, Thirumala S, Kiran BR (2011) Fish diversity in relation to Physicochemical characteristics of Bhadra reservoir of Karnataka, India. Advances in Applied Science Research 2: 34-47.

15. Offem BO, Ayotunde EO, Ikpi GU, Ochang SN, Adaet FB (2011) Influence of Seasons on Water Quality, Abundance of Fish and Plankton Species of Ikwori Lake, South-Eastern Nigeria. Fisheries and Aquaculture Journal 13.

16. Mason CF (1992) Biology of fresh water pollution. New York. Wiley and Sons.

17. Alabaster JS (1982) Report of the EIFAC. Workshop on fish farm effluents. Technical Paper 41, FAO, Rome. Italy 1-166.
18. Trivedi S, Kataria HC (2012) Physico-Chemical Studies of Water Quality of Shahpura Lake, Bhopal (M.P) with Special Reference to Pollution Effects on Ground Water of its Fringe Areas. International Research Journal of Environmental Science 7: 139- 144

19. Hassan FM, Saleh MM, Salman JM (2009) A Study of Physicochemical Parameters and Nine Heavy Metals in the Euphrates River, Iraq. E-J Chem 7: 685-692.

20. Bhatti MT, Latif M (2011) Assessment of water quality of a river using an indexing approach during the low-flow season. Irrigation Drainage 60: 103114

21. Ufodike EB, Kwanasie AS, Chude LA (2001) On-set of rain and its destabilizing effect on aquatic physicochemical parameters. Journal of aquatic sciences 16: 91-94.

22. Ugwu Al, Wakawa RJ (2012) A study of seasonal physicochemical parameters in river Usma. American Journal of Environmental Science 8: 569-576.

23. UNICEF (2008) UNICEF handbook on water quality. United Nations Childrens Fund, New York/USA.

24. Smith RL (1990) Ecology and Field Biology (4th edn) Harper Collins Publishers, New York.

25. Albert Moses S, Janaki L, Joseph S, Kizhur Kandathil R (2014) Determining the spatial variation of phosphorus in a lake system using remote sensing techniques. Lakes \& Reservoirs: Research \& Management 19: 24-36.

26. Singleton H (2000) Ambient water quality guidelines for sulphate: technical appendix. Ministry of Environment, Lands and Parks, Province of British Columbia, Canada.

27. Kerekes J, Beauchamp S, Tordon R, Pollock T (1987) Sources of sulphate and acidity in wetlands and lakes in Nova Scotia. Acidic Precipitation 1261-1268.

28. Khan SA, Khan M (1997) Water quality characteristics of the Kabul River in Pakistan under high flow conditions. J Chem Soc Pak 19: 205- 210

29. Dankwa HR, Abban EK, Teugels GG (1999) Freshwater fishes of Ghana: identification, distribution, ecological and economic importance. Annales de la Société Royale Zoologique de Belgique 283: 1-53.

30. Andah El, Van de Giesen N, Charles A (2003) Water, Climate, Food, and Environment in the Volta Basin. Contribution to the project ADAPT Adaptation strategies to changing environments. Water Evaluation and Planning system (WEAP), Stockholm. Sweden.

31. Andah W, Gichuki F (2003) Volta basin profile: strategic research for enhancing agricultural water productivity (Draft). Accra: International Water Management Institute. CGIAR Challenge Program on Water and Food.

2. Goudswaard PC, Avoke SK (1993) Fish species in the northern arm of Lake Volta. Integrated Development of Artisanal Fisheries Project unpublished report. Rome, FAO 19.

33. Ofori-Danson PK, Ntow WJ (2005) Studies on the current state of the limnochemistry and potential fish yield of Lake Volta (Yeji sector) after three decades of impoundment. Ghana Journal of Agricultural Science 38: 65- 72.

34. Oguntunde PG, Friesena J, Giesena N, Savenijea HG (2006) Hydro climatology of the Volta River Basin in West Africa: Trends and variability from 1901 to 2002. Elsevier, Academic Press 31: 1180-1188.

35. Van Zwieten PAM, Béné C, Kolding J, Brummett R, Valbo-Jorgensen J (2011) Review of tropical reservoirs and their fisheries - The cases of Lake Nasser Lake Volta and Indo-Gangetic Basin reservoirs. FAO Fisheries and Aquaculture Technical Paper No 557 